\title{
Pengaruh CAR, LDR, BOPO, dan KAP terhadap non performing loan BPR konvensional di Kota Batu sebelum dan setelah COVID-19
}

\author{
Refo Putraseto, Imam Mukhlis* \\ Universitas Negeri Malang, Jl. Semarang No. 5 Malang, Jawa Timur, Indonesia \\ *Penulis korespondensi, Surel: imam.mukhlis.fe@um.ac.id
}

Paper received: 25-8-2021; revised: 8-9-2021; accepted: 15-9-2021

\begin{abstract}
This study aims to investigate the effects of CAR, LDR, BOPO, and KAP on conventional BPR NPLs in Batu City before and after COVID-19. This quantitative research employed panel data methods and descriptive analysis methods. The panel data method was used to analyze data before COVID-19 (2015-2019), while descriptive analysis was used to analyze data after COVID-19 (2020). The secondary data was also used in this study because the researchers took data in the form of official published reports obtained from the OJK official website and processed through the Eviews 9 application. Through data processing, the results showed that the CAR, LDR, and BOPO variables carries a significant influence on NPL in rural banks. Meanwhile, in conventional method in Batu City, the KAP variable does not have a significant effect on NPL. The results of descriptive analysis during the COVID-19 pandemic suggest that the NPL ratio in 2020 was above $5 \%$ and tends to increase. The increase in the NPL ratio in 2020 is because debtors have difficulty paying/paying off their obligations as a result of their declining income due to the impact of COVID-19 on various fields. Many people have been laid off, laid off, have their salaries cut, or sales have slowed as a result of COVID19 , so it affects them when they have installments at banks like conventional BPRs
\end{abstract}

Keywords: NPL; CAR; LDR; BOPO; KAP; COVID-19

\begin{abstract}
Abstrak
Penelitian ini bertujuan untuk menganalisa pengaruh dari CAR, LDR, BOPO, dan KAP pada BPR NPLS konventional di Kota Batu, sebelum dan sesudah Covid-19. Penelitian ini menggunakan pendekatan kuantitative dengan metode data panel dan analisis deskriptif. Metode panel data digunakan untuk analisa data sebelum Covid-19 (2015-2019), sedangkan metode analisis deskriptif digunakan untuk menganalisa data setelah Covid-19 (2020). Selain itu, data sekunder juga digunakan karena penelitian ini menggunakan data dari laporan yang diterbitkan oleh OJK dan di analisa menggunakan aplikasi Eviews 9. Hasil dari analisa data menunjukan bahwa $C A R, L D R$, dan BOPO memberikan dampak yang signifikan kepada NPL pada bank-bank daerah. Sedangkan pada metode konvensional di Kota Batu, KAP tidak memberikan dampak yang signifikan pada NPLnya. Analisa descriptive pada masa Covid-19 menunjukkan bahwa rasio NPL pada tahun 2020 berada di atas $5 \%$ dan menunjukkan kecenderungan untuk naik. Kenaikan rasio NPL pada tahun 2020 disebabkan oleh ketidakmampuan para peminjam untuk memenuhi kewajiban mereka dikarenakan berkurangnya pendapatan mereka dikarenakan oleh Covid-19. Selain itu, banyaknya jumlah pekerja yang diberhentikan dari pekerjaan, mengalami pemotongan gaji, dan penurunan produksi dan penjualan karena Covid-19, mempengaruhi pelunasan cicilan pada bank, seperti konvensional BPR.
\end{abstract}

Kata kunci: NPL; CAR; LDR; BOPO; KAP; COVID-19

\section{Pendahuluan}

Di Indonesia bank menjadi institusi atau lembaga pada bidang finance dengan peran penting terkait kegiatan perekonomian terutama menyangkut fungsi intermediasi yang diembannya sesuai dengan UU Nomor 10 Tahun 1998, dimana bank akan mengumpulkan 
uang/dana yang asalnya dari masyarakat melalui simpanan lalu menyalurkannya kembali dana tersebut melalui pinjaman yang dapat diakses masyarakat yang memerlukan dana. Secara umum ada dua macam bank, yaitu bank umum \& BPR. BPR ialah salah satu bank dengan aktivitas utamanya berfokus pada kegiatan konvensional atau syariah yang kaitannya dengan penyaluran dana maupun penghimpunan dana, dimana ketika pelaksanaan operasionalnya BPR tak menyuguhkan jasa yang berkaitan dengan penyetoran apapun karena hal tersebut telah diatur dalam UU No. 10 Tahun 1998. Utamanya kegiatan usaha Bank Perkreditan Rakyat ini ditujukan dalam melayani masyarakat yang tinggal di pedesaan dan memberikan pelayanan kepada pelaku usaha kecil atau mikro seperti UMKM. Jumlah BPR konvensional di Indonesia juga tergolong banyak, dimana per Desember 2019 mencapai 4.967. BPR dalam menjalankan kegiatan penyaluran kredit tentunya juga memiliki risiko yang harus dihadapi. Risiko tersebut akan merugikan bank terutama terkait laba perusahaan jika tak ada pengelolaan yang optimal ((Khan, Siddique, \& Sarwar, 2020)

Satu risiko yang pasti akan dihadapi oleh BPR ketika memberikan pinjaman yaitu kredit bermasalah atau tunggakan kewajiban. Bertambah besarnya total pinjaman yang disalurkan bank mau tak mau konsekuensi akan diperoleh bank dengan semakin besarnya risiko yang ditanggung kedepannya. Risiko kredit bermasalah atau pinjaman yang macet sendiri terdeteksi dari rasio Non Performing Loan bank tersebut, dimana nilai NPL berfungsi dalam pengukuran mampu tidaknya bank untuk menanggung kegagalan terkait pengembalian kredit yang dilakukan oleh pihak debitur karena pihak debitur tidak bisa membayar pinjaman kreditnya secara terus-menerus, baik itu pembayaran bunga pinjaman maupun pokok pinjaman yang telah diatur dalam persyaratan perjanjian kredit secara tertulis. NPL atau kredit bermasalah ini tentunya dapat berdampak negatif pada likuiditas bank.

Peningkatan NPL dalam rentang waktu 2015-2020 tersebut sejalan dengan permasalahan yang mendera BPR di Indonesia. Menurut Otoritas Jasa Keuangan, sejumlah permasalahan yang nampak pada BPR umumnya disebabkan oleh masalah internal seperti keterbatasan modal, kurangnya tata kelola yang baik, kualitas dan kuantitas SDM masih kurang baik, biaya dana yang mahal, serta masih belum variatifnya produk dan layanan BPR. Faktor eksternal yang menimbulkan permasalahan bagi BPR yaitu adanya persaingan usaha dengan bank-bank lainnya maupun dengan fintech atau pinjaman online. Banyak BPR yang kolaps dan izin usahanya dicabut oleh OJK karena mayoritas terkena masalah Good Corporate Governance atau tata kelola manajemen BPR masih kurang baik. Apalagi memasuki tahun 2020 bebarengan dengan masa pandemi yang efek buruknya menjalar ke berbagai sector termasuk bidang perbankan atau finance. Dengan adanya pandemi COVID-19 mengakibatkan penyaluran kredit terganggu dan meningkatkan potensi kredit bermasalah. Adanya pandemi COVID-19 menyebabkan banyak pekerja memperoleh suatu hal yang tidak diinginkan seperti mengalami PHK, dirumahkan, ataupun pemotongan gaji. Selain itu, para pelaku usaha seperti UMKM juga mengalami penurunan penjualan dan penurunan pendapatan. Kondisi tersebut mau tak mau membuat mereka yang memiliki pinjaman di bank seperti BPR akan mengalami kendala dalam hal pembayaran angsuran. Hal tersebut dikarenakan para nasabah/debitur kesulitan membayar angsurannya di bank akibat pendapatan yang menurun, imbas dari pandemi COVID-19. Rasio kredit bermasalah pada BPR konvensional di Indonesia terus melonjak pada bulan April semenjak terdapat COVID-19. Pada bulan Juli 2020 rasionya telah mencapai angka 8,34\% dan pada masa sebelum pandemi (Januari-Maret 2020) yaitu berada di angka 7,26\%, $7,53 \%$, dan 7,95\%. bantuan program restrukturisasi oleh 0JK bertujuan untuk menjaga rasio NPL BPR agar tidak menjadi semakin besar karena dampak pandemi COVID-19 ini. Namun, 
kecenderungan peningkatan NPL BPR masih tetap ada karena tidak diimbangi dengan pertumbuhan kredit yang sehat. BPR yang dapat menjaga rasio NPL nya di masa pandemi biasanya menyalurkan kreditnya sebagian besar kepada ASN, TNI, dan Polri karena mereka tidak terlalu terdampak COVID-19.

Penelitian dari Maya Rosita \& Musdholifah (2016) menyebutkan jika CAR mempunyai efek negatif signifikan pada NPL. Terdapat perbedaan hasil karena hasilnya berbanding terbalik dengan penelitian Anthony Wood \& Nakita Skinner (2018) yang memperlihatkan bahwa CAR mempunyai efek positif signifikan pada NPL. Penelitian Anthony Wood \& Nakita Skinner (2018) menyebutkan jika LDR mempunyai efek secara positif signifikan pada NPL, tetapi berbanding terbalik dengan hasil dari Shinta Anggun Kinanti (2017) memperlihatkan jika LDR memiliki pengaruh secara negatif signifikan terhadap NPL. Penelitian dari Shinta Anggun Kinanti (2017) memperlihatkan jika variabel BOPO mempunyai efek positif signifikan pada NPL. Penelitian terkait Kualitas Aktiva Produktif dari M.Umar dan Gang Sun (2018) memperlihatkan jika KAP mempunyai efek positif signifikan pada NPL.

Melalui semua uraian dan penjabaran latar belakang membuat peneliti berminat untuk menjalankan penelitian lebih dalam mengenai apakah faktor-faktor internal dalam perbankan menjadi penyebab suatu bank terkena kredit bermasalah atau berpengaruh terhadap NPL. Penelitian ini dilakukan terhadap BPR konvensional yang ada di Kota Batu dengan jumlah 5 BPR karena sejauh ini masih belum ditemukan penelitian terdahulu yang membahas tentang kredit bermasalah pada BPR konvensional di Kota Batu dan dari data NPL pun terlihat bahwa mayoritas BPR konvensional di Kota Batu memiliki NPL di atas 5\% dalam periode 5 tahun terakhir dan berharap penelitian ini bisa bermanfaat serta menjadi sebuah pembaruan dari penelitian sebelumnya. Peneliti juga tertarik dalam melakukan pengujian lebih lanjut demi mengetahui temuan terkait penilaian kinerja bank apabila diterapkan dalam kondisi lingkungan yang berbeda dari penelitian terdahulu karena juga penelitian sebelumnya memiliki hasil yang bervarian dan berbeda-beda. Dari latar belakang serta research gap tadi menjadikan peneliti berminat untuk menjalankan penelitian skripsi dengan judul "Pengaruh CAR, LDR, BOPO, dan KAP Terhadap Non Performing Loan BPR Konvensional di Kota Batu Sebelum dan Setelah COVID-19".

Teori Sinyal (Signalling Theory), sinyal atau isyarat ialah sebuah upaya dari perusahaan untuk menyajikan suatu petunjuk bagi investor terkait cara pandang manajemen terhadap kemajuan perusahaan kedepannya (Brigham \& Houston, 2014)(Brigham dan Houston, 2001:36). Isyarat tersebut dapat berupa sajian info perihal kinerja manajemen ketika dituntut memenuhi target dari owner perusahaan. Sinyal berupa informasi itu menjadi satu bagian penting untuk pihak luar berinvestasi atau tidak pada perusahaan tersebut. Investor maupun pelaku bisnis akan melihat informasi dari perusahaan yang menunjukkan gambaran dan keterangan baik buruknya kondisi ketika masa sebelumnya maupun masa mendatang.

Penggambaran perusahaan yang memiliki alasan untuk mendorong penyajian informasi menyangkut laporan keuangan kepada pihak luar perusahaan dibahas melalui teori sinyal. Terdapatnya ketidaksesuaian informasi antar pihak luar perusahaan bersama perusahaan itu sendiri menjadi asal muasal perusahaan mendorong penyajian laporan keuangan. Hal itu disebabkan oleh perusahaan yang mengetahui lebih dalam terkait kondisi dan prospek perusahaan tersebut dibandingkan dengan pihak eksternal seperti kreditur maupun investor. Berkurangnya informasi asimetri dapat meningkatkan nilai perusahaan. Jadi, pemberian sinyal 
kepada pihak eksternal dapat mengurangi informasi asimetri tersebut (Arifin, 2009:11). Apabila laba perusahaan dalam posisi naik, maka informasi tersebut merupakan sinyal yang baik, sedangkan apabila laba perusahaan dalam posisi menurun, maka informasi tersebut merupakan sinyal yang buruk.

Terkait penelitian ini terdapat asumsi jika semakin besar rasio NPL atau kredit bermasalah di laporan keuangan bank menjadikan masyarakat memandang bank berkinerja buruk. Hal tersebut merepresentasikan jika manajemen bank yang bersangkutan masih belum optimal dan inefisien ketika mengatur finansialnya. Dengan demikian, teori sinyal ini relevan jika menjadi sebuah acuan pada penelitian kali ini sebab sinyal serta informasi terkait NPL telah dirilis dan bisa diakses masyarakat yang mana bisa berimbas pada upaya yang dipilih dan dapat mempengaruhi tingkat kesehatan serta kelangsungan hidup suatu bank.

Non Performing Loan (NPL), tingginya nilai NPL merupakan sebuah indikator kegagalan bank dalam mengelola kegiatan usaha dengan munculnya permasalahan terkait likuiditas (pembayaran pihak ketiga tidak mampu dilakukan bank), rentabilitas (penagihan utang tidak dapat dilakukan), dan solvabilitas (berkurangnya modal). Kredit bermasalah identik dengan sulitnya penyelesaian kewajiban-kewajiban oleh debitur kepada bank terutama dalam membayar kembali angsuran pokok kredit, bunga, dan ongkos-ongkos bank yang seharusnya sudah menjadi beban bagi debitur tersebut dan telah tertuang melalui perjanjian kredit atau PK (Dendawijaya, 2005:82). Angka 5\% menjadi batas rasio NPL sebab menjadi ketetapan Bank Indonesia. Berikut ini rumus penghitungan nilai NPL.

$$
N P L=\frac{\text { Kredit Bermasalah }}{\text { Total Kredit }} \times 100 \%
$$

Capital Adequacy Ratio (CAR) ialah rasio dengan menyangkut tercukupnya modal dengan tujuan mewadahi segala risiko dari ketidakuntungan bank ketika menjalani kegiatan operasionalnya (Dendawijaya, 2005:121). Jika CAR naik dapat diakibatkan oleh peningkatan modal yang dimiliki bank atau penurunan nilai ATMR. Ketika nilai ATMR menurun maka terdapat indikasi semakin kecilnya risiko kredit yang ditanggung bank. Semakin tingginya nilai CAR akan menunjukkan kemampuan modal bank untuk menanggung aktiva produktif atau kredit yang berisiko semakin baik (Asif Khan et al., 2020). Jumlah modal yang semakin besar dapat memperkecil peluang risiko kredit bermasalah atau memperkecil peluang meningkatnya NPL. Berdasarkan peraturan Bank Indonesia, umumnya besarnya CAR yang menjadi standar bagi masing-masing bank saat ini yaitu minimal $8 \%$. Rumus perhitungan CAR yaitu sebagai berikut:

$$
C A R=\frac{\text { Modal }}{A T M R} \times 100 \%
$$

Loan to Deposit Ratio (LDR) ialah suatu metode dengan mengkomparasikan semua total pinjaman yang digelontorkan bank dan dana yang sukses didapatkan bank (modal sendiri serta dana dari pihak ketiga). Rasio LDR menampilkan mengenai keahlian bank untuk kembali melakukan pembayaran atas ditariknya dana oleh deposan, kemudian memanfaatkan pemberian pinjaman menjadi sumber likuiditasnya (Dendawijaya, 2005:116). Rasio ini juga digunakan dalam melihat tingkat keahlian bank dalam penyaluran dananya dari pihak ketiga seperti deposan dan menjadi isyarat apakah pinjaman dibatasi atau bisa melakukan ekspansi. 
Apabila LDR suatu bank tinggi menyebabkan bank memiliki risiko sulit tertagihnya tunggakan kredit dan hal tersebut dapat mengakibatkan mengalami kerugian (Latumaerissa, 2014).

Dilihat dari SE BI No. 6/23/DPNP tahun 2004 bisa dijabarkan jika angka 85\% menjadi batas bawah nilai LDR, sedangkan angka $100 \%$ menjadi batas atasnya. Rumus penghitungan LDR yaitu sebagai berikut:

$$
L D R=\frac{\text { Total Kredit }}{D P K+\text { Modal Inti }} \times 100 \%
$$

Biaya Operasional Pendapatan Operasional (BOPO) termasuk dalam metode pengukuran rentabilitas. Pengukuran taraf efisiensi serta pengukuran keahlian bank ketika mengoperasikan kegiatannya merupakan fungsi dari rasio BOPO ini (Dendawijaya, 2005). Karena menyangkut efisiensi, BOPO berguna pula dalam melihat mampu tidaknya manajemen ketika mengefisiensikan biaya yang dikeluarkan untuk operasional terhadap pemasukan bank (Kuncoro dan Suhardjono, 2009). Rasio BOPO umumnya mempunyai efek positif pada NPL dikarenakan kian kecilnya BOPO membuat kondisi problematis pada bank pun kian kecil, sehingga kian besar BOPO menjadikan nilai NPL kian bertambah pula. Sebagai pengukur efisiensi operasi, menurut ketentuan Bank Indonesia nilai BOPO haruslah berada di bawah 94\%. Rumus penghitungan rasio BOPO yaitu sebagai berikut:

$$
\text { BOPO }=\frac{\text { Biaya Operasional }}{\text { Pendapatan Operasional }} \times 100 \%
$$

Kualitas Aktiva Produktif (KAP) ialah suatu rasio dengan kegunaan mengukur jenis-jenis aset pada bank. Tujuan dari dinilainya aktiva atau kualitas aset yaitu melihat keadaan aset suatu bank yang di dalamnya tercantum antisipasi dari risiko kegagalan pembayaran proses kredit atau proses pembiayaan (Soebagio, 2005). Kredit pun memiliki kualitasnya sendirisendiri, seperti lancar, kurang lancar, dan macet (Taswan, 2010). KAP bermasalah tentunya dapat mempengaruhi NPL, dimana kualitas aktiva yang memiliki masalah menjabarkan seberapa besar aset tersebut belum bisa menyediakan pemasukan bagi bank. Rasio KAP umumnya mempunyai efek terhadap NPL secara positif dan signifikan, dimana jika terjadi penurunan KAP bermasalah pada bank membuat penurunan NPL pun bisa terjadi. Rasio KAP yang sehat yaitu dibawah 10,35\% dan rasio KAP yang tidak sehat berada diatas 14,85\%. Berikut ini terdapat rumus perhitungan Kualitas Aktiva Produktif:

$$
K A P=\frac{A P D}{A P} \times 100 \%
$$

Hubungan Variabel CAR terhadap NPL: CAR ialah rasio yang menyangkut kecukupan modal dengan tujuan mewadahi segala risiko dari ketidakuntungan bank ketika menjalani kegiatan operasionalnya (Dendawijaya, 2005:121). Pada bank, jika memiliki modal atau rasio CAR yang tinggi dapat menampung aktiva produktif yang memiliki risiko seperti dalam kegiatan kredit. Jumlah modal bank yang besar dapat memperkecil peluang kredit bermasalah. Sebaliknya, penyaluran kredit yang tinggi pada bank dan tidak diimbangi dengan tercukupnya modal membuat peluang probemalitas pinjaman kian besar. Atas dasar itulah dapat ditarik kesimpulan jika CAR berpengaruh negatif terhadap NPL.

Hubungan Variabel LDR terhadap NPL: LDR ialah suatu rasio dengan mengkomparasikan semua total kredit yang digelontorkan bank dan dana yang sukses 
didapatkan bank (modal sendiri serta dana dari pihak ketiga) (Dendawijaya, 2005). Dana dari pihak ketiga tentunya akan digunakan bank untuk penyaluran kredit yang mana dapat mempengaruhi pula rasio LDR pada bank dan tidak menutup kemungkinan banyaknya dana yang disalurkan dalam kredit dapat berpengaruh pada peningkatan NPL. Maka dari itu hal tersebut menandakan jika rasio LDR mempunyai efek positif pada NPL.

Hubungan Variabel BOPO terhadap NPL: Perbandingan pada biaya operasional dengan pemasukan di bank dapat dilihat melalui rasio BOPO (Dendawijaya, 2005). Semakin kecilnya BOPO dapat diartikan jika pengeluaran biaya operasional oleh bank menjadi efisien serta kinerja manajemen bank semakin baik pula. Apabila BOPO tinggi, dapat diartikan jika pendapatan operasional lebih kecil daripada biaya operasional dan turut mempengaruhi peningkatan NPL karena bank tidak efisien dalam mengoperasikan keuangannya, sehingga risiko kredit bermasalah akan tinggi. Atas dasar itulah dapat dikatakan jika BOPO berpengaruh positif terhadap NPL.

Hubungan Variabel KAP terhadap NPL: KAP ialah suatu rasio dengan kegunaan mengukur jenis-jenis aset pada bank. Tujuan dari dinilainya aktiva atau kualitas aset yaitu melihat keadaan aset suatu bank yang di dalamnya tercantum antisipasi dari risiko kegagalan pembayaran proses kredit atau proses pembiayaan (Soebagio, 2005). KAP ini berkaitan dengan kualitas kredit yang ada dalam bank termasuk kredit bermasalah. Besarnya rasio KAP bermasalah tentunya memperlihatkan jika penyaluran kredit mengalami masalah karena banyaknya pinjaman yang mempengaruhi peningkatan NPL seperti dalam keadaan macet, kurang lancer, ataupun diragukan. Atas dasar itulah dapat dikatakan jika KAP berpengaruh positif terhadap NPL.

\section{Metode}

Disini penelitiannya memakai pendekatan metode kuantitatif dengan menggunakan data sekunder pada periode waktu 2015-2019 (sebelum COVID-19) serta tahun 2020 ketika bebarengan terjadinya pandemi. Analisis regresi data panel dan analisis deskriptif ialah teknik analisis data yang digunakan. Analisis regresi data panel berguna dalam menganalisis data sebelum COVID-19 (tahun 2015-2019), sedangkan analisis deskriptif digunakan untuk menganalisis data saat terjadi COVID-19 (tahun 2020). Peneliti memakai aplikasi Eviews 9 ketika menganalisis data panel. Model penelitian menggunakan data panel 5 BPR konvensional di Kota Batu 2015-2019. Pemakaian datanya ialah data triwulanan yang didapatkan dari laporan publikasi resmi Otoritas Jasa Keuangan (OJK) yang meliputi data dari variabel NPL (Y), CAR (X1), LDR (X2), BOPO (X3), dan KAP (X4).

Model persamaan regresi sebagai berikut:

$$
Y i t=\beta 0+\beta 1 X 1 i t+\beta 2 X 2 i t+\beta 3 X 3 i t+\beta 4 X 4 i t+e i t
$$

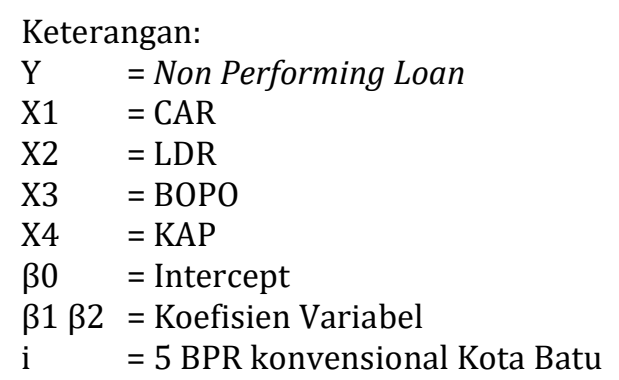


$\begin{array}{ll}\mathrm{t} & =\text { Tahun } \\ \mathrm{e} & =\text { Error term }\end{array}$

Ketika menggunakan data panel di penelitian harus terlebih dahulu memilih teknik estimasi model regresi yang terdapat 3 pendekatan, meliputi Common Effects Model, Fixed Effects Model, dan Random Effects Model. Jika sudah memilih metode estimasi lalu akan dilanjutkan pemilihan model regresi data panel yang terdapat tiga pengujiannya, seperti Uji Chow berguna dalam penentuan FEM atau CEM, Uji Hausman berguna dalam penentuan FEM atau REM, dan Uji Lagrange Multiplier berguna dalam penentuan REM atau CEM (Widarjono, 2013). Model penelitian tentunya harus diikuti dengan uji asumsi klasik serta uji hipotesis untuk melihat standar statistik serta asumsi penelitian, dengan catatan kedua uji itu harus bisa dipenuhi.

Uji asumsi klasik sendiri mempunyai 4 uji yaitu uji normalitas dalam mengidentifikasi data berdistribusi normal atau tidak, tetapi ketentuannya nilai Jarque-Bera lebih dari 0,05. Uji multikolinearitas untuk melihat hubungan linear antara variabel independen dengan syarat nilai korelasinya masing-masing variabel independen dibawah 0,85 . Uji heteroskedastisitas berguna dalam mengidentifikasi terpautnya varian dari residual satu pengamatan ke pengamatan lainnya dengan syarat nilainya lebih dari signifikansi 0,05. Uji autokorelasi berguna dalam mengidentifikasi apa ada korelasi antara kesalahan pengganggu pada periode tertentu dengan kesalahan pengganggu pada periode sebelumnya dengan memperhatikan nilai tabel Durbin Watson sebagai acuannya (Gujarati \& Porter, 2013).

Sementara itu uji hipotesis didalamnya mempunyai 3 uji. Uji $\mathrm{T}$ berguna dalam mengidentifikasi efek secara parsial antara variabel independen terhadap variabel dependen dengan catatan nilai t-hitung lebih dari 0,05 artinya tidak signifikan dan t-hitung kurang dari 0,05 artinya signifikan. Lalu, Uji F untuk melihat secara simultan efek dari variabel independen terhadap variabel dependen dengan memperhatikan nilai f-hitung lebih dari f-tabel. Terakhir, koefisien determinasi atau Uji $\mathrm{R}^{2}$ berguna dalam mengidentifikasi besarnya variabel independen menjelaskan variabel dependen, sisanya dipengaruhi oleh variabel lain diluar penelitian.

Teknik analisis deskriptif digunakan untuk mendeskripsikan bagaimana kondisi variabel CAR, LDR, BOPO, dan KAP pada masa setelah pandemi COVID-19. Analisis deskriptif sendiri pada penelitian ini akan melihat dan menjabarkan hasil dari nilai minimum, nilai maksimum, mean, dan standar deviasi.

\section{Hasil dan Pembahasan}

\subsection{Hasil}

\subsubsection{Hasil Analisis Regresi Data Panel}

Berikut ini terdapat perbandingan 3 model estimasi data panel mulai dari model CEM, FEM, dan REM: 
Jurnal Ekonomi, Bisnis dan Pendidikan, 1(9), 2021, 806-823

Tabel 1. Perbandingan Estimasi Model Regresi Data Panel

\begin{tabular}{llll}
\hline \multirow{2}{*}{ Variabel } & CEM & FEM & REM \\
\cline { 2 - 4 } & Prob. & Prob. & Prob. \\
\hline CAR & 0.0000 & 0.0225 & 0.0000 \\
LDR & 0.2129 & 0.0026 & 0.0941 \\
BOPO & 0.0000 & 0.0083 & 0.0000 \\
KAP & 0.6438 & 0.9085 & 0.5331 \\
C & 0.0017 & 0.0539 & 0.0000 \\
\hline
\end{tabular}

Sumber: Data diolah, 2021

Melalui tabel di atas bisa didapatkan hasil jika masing-masing model estimasi tersebut berbeda-beda sehingga perlu dilakukan pengujian untuk memilih model estimasi terbaik melalui Uji Chow serta Uji Hausman.

Pada Uji Chow terdapat dua hipotesis yang digunakan yaitu $\mathrm{H}_{0}$ (CEM) dan $\mathrm{H}_{1}$ (FEM).

Tabel 2. Hasil Uji Chow

\begin{tabular}{lcll}
\hline Effects Test & Statistic & d.f. & Prob. \\
\hline & & & \\
Cross-section F & 20.435974 & $(4,91)$ & 0.0000 \\
Cross-section Chi-square & 64.095063 & 4 & 0.0000 \\
\hline
\end{tabular}

Sumber: Data diolah 2021

Dari hasil uji chow pada tabel diatas terlihat bahwa nilai probabilitas cross section $\mathrm{F}$ sebesar 0,0000 dimana nilai tersebut kurang dari nilai signifikansi 0,05 $(0,0000<0,05)$, sehingga model yang terpilih yaitu Fixed Effect Model (FEM).

Pada Uji Hausman terdapat dua hipotesis yang digunakan yaitu $\mathrm{H}_{0}(\mathrm{REM})$ dan $\mathrm{H}_{1}$ (FEM).

Tabel 3. Hasil Uji Hausman

\begin{tabular}{lll}
\hline Test Summary & Statistic & Prob. \\
\hline Cross-section random & 81.743897 & 0.0000 \\
\hline Sumber: Data diolah, 2021 & &
\end{tabular}

Dari hasil uji hausman terlihat bahwa nilai probabilitas cross section random sebesar 0,0000 dimana nilai tersebut lebih kecil dari nilai signifikansi 0,05 $(0,0000<0,05)$, sehingga H0 ditolak dan H1 diterima, maka model yang terpilih yaitu Fixed Effect Model (FEM).

Periode waktu yang dipakai di penelitian ini ketika menggunakan data panel yaitu dari tahun 2015 hingga tahun 2019 (sebelum COVID-19) dengan model data triwulanan serta datanya setara dengan 20 periode penelitian dengan jumlah unit cross section sebanyak 5 sampel. Hal tersebut juga menunjukkan jumlah t lebih besar dari jumlah n. Pemilihan sampel menggunakan gabungan teknik purposive sampling dan random sampling karena dibutuhkan kriteria khusus dalam memilih sampel yaitu BPR yang tidak mengalami penutupan atau masih aktif dari rentang tahun 2015-2020, karena dari populasi 8 BPR ada yang sudah tidak aktif lagi. Kemudian dari BPR yang masih aktif dipilih sampel secara acak dan terbentuklah 5 BPR sebagai sampel penelitian. 
Dilihat dari hasil Uji Chow dan Uji Hausman dapat diperoleh model estimasi yang terbaik yaitu model Fixed Effect Model (FEM).

Tabel 4. Hasil FEM

\begin{tabular}{lll}
\hline NPL & Koefisien & p value \\
\hline CAR & 0.092782 & 0.0225 \\
LDR & -0.126873 & 0.0026 \\
BOPO & 0.072815 & 0.0083 \\
KAP & -0.000600 & 0.9085 \\
C & 10.84282 & 0.0539 \\
\hline
\end{tabular}

Sumber: Data diolah, 2021

Melalui tabel di atas dapat ditentukan model regresi yang terbentuk yaitu:

$$
\mathrm{Y}=\mathbf{1 0 . 8 4 2 8 2}+0.0927821 \mathrm{it}-\mathbf{0 . 1 2 6 8 7 3 2 i t}+0.0728153 \mathrm{it}+0.0006004 \mathrm{it}+\mathrm{eit}
$$

Nilai konstanta sebesar 10.84282 memperlihatkan jika variabel CAR, LDR, BOPO, dan KAP bernilai konstan, maka NPL secara rasional sebesar 10.84282 .

Nilai koefisien CAR sebesar 0.092782 dan bertanda positif. Artinya memperlihatkan hubungan yang searah dengan NPL. Ketika CAR meningkat sebesar 1\%, maka NPL akan naik sebesar 0.092782 .

Nilai koefisien LDR sebesar -0.126873 dan bertanda negatif. Artinya memperlihatkan hubungan yang berlawanan arah dengan NPL. Ketika LDR meningkat sebesar 1\%, maka NPL akan menurun sebesar -0.126873 .

Nilai koefisien BOPO sebesar 0.072815 dan bertanda positif. Artinya memperlihatkan hubungan yang searah dengan NPL. Ketika BOPO meningkat sebesar 1\%, maka NPL akan meningkat sebesar 0.072815 .

Nilai koefisien KAP sebesar 0.000600 dan bertanda positif. Artinya memperlihatkan hubungan yang searah dengan NPL. Ketika KAP meningkat sebesar 1\%, maka KAP akan meningkat sebesar 0.000600 .

\subsubsection{Hasil Uji Asumsi Klasik}

\subsubsection{Uji Normalitas}

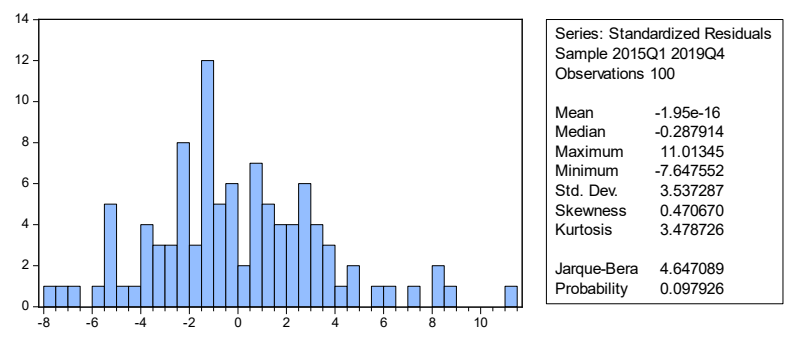

Gambar 1. Hasil Uji Normalitas

Sumber: Data diolah, 2021 
Pada gambar diatas bisa diketahui jika nilai probabilitas JB dalam penelitian ini yaitu sebesar 0.097926, dapat dikatakan nilai tersebut lebih besar dari nilai signifikansi 0,05 serta menunjukkan data telah berdistribusi normal.

\subsubsection{Uji Multikolinearitas}

Tabel 5. Hasil Uji Multikolinearitas

\begin{tabular}{lllll}
\hline & CAR & LDR & BOPO & KAP \\
\hline CAR & 1.00000 & - & - & - \\
& 0 & 0.04428 & 0.07267 & 0.18364 \\
LDR & - & 3 & 9 & 2 \\
& 0.04428 & 0 & - & 0.07898 \\
& 3 & & 2 & 7 \\
BOPO & - & - & 1.000000 & - \\
& 0.07267 & 0.15924 & 0 & 0.11649 \\
\multirow{4}{*}{ KAP } & 9 & 2 & & 8 \\
& - & 0.07898 & - & 1.00000 \\
& 0.18364 & 7 & 0.11649 & 0 \\
\hline
\end{tabular}

Sumber: Data diolah, 2021

Melalui tabel tersebut bisa diketahui jika angka korelasi antar variabel independen kurang dari 0,85. Hal tersebut menunjukkan model penelitian ini tidak mengandung masalah multikolinearitas.

\subsubsection{Uji Heteroskedastisitas}

Tabel 6. Hasil Uji Heteroskedastisitas

\begin{tabular}{ll}
\hline Variabel & Prob. \\
\hline CAR & 0.5224 \\
LDR & 0.3243 \\
BOPO & 0.2669 \\
KAP & 0.5097 \\
\hline
\end{tabular}

Sumber: Data diolah, 2021

Menurut hasil uji heteroskedastisitas pada tabel diatas bisa diketahui jika keseluruhan variabel independen nilai probabilitasnya diatas 0,05 . Hal tersebut menunjukkan penelitian ini tidak mengalami gejala heteroskedastisitas.

\subsubsection{Uji Autokorelasi}

Tabel 7. Hasil Uji Autokorelasi

\begin{tabular}{ll}
\hline Durbin Watson Stat 1.071366 \\
\hline Sumber: Data diolah, 2021
\end{tabular}

Untuk nilai $\mathrm{n}=100$ serta $\mathrm{k}=4$, menjadikan nilai $\mathrm{dL}=1.5922 \mathrm{dan} \mathrm{dU}=1.7582$. Melalui tabel di atas bisa diketahui jika nilai Durbin-Watson statistik untuk FEM yaitu 1.071366. 
Karena $\mathrm{d}=1.071366$ dan $\mathrm{dL}=1.5922$, maka $0<d<d_{L}(0<1.071366<1.5922)$ yang menunjukkan bahwa hipotesis nol ditolak dan dalam model regresi masih terdapat autokorelasi positif. Namun, metode GLS bisa menekan autokorelasi yang kadang kala muncul pada rumus OLS akibat dari kesalahan estimasi varians, yang mana hal tersebut membuat masalah pada autokorelasi di metode GLS bisa diatasi. Pemakaian FEM sebagai model estimasi data panel dengan sifat LSDV ataupun GLS bisa tidak menghiraukan adanya masalah autokorelasi. Selain itu, pada model estimasi dengan pendekatan OLS tidak semua uji asumsi klasik digunakan untuk pengujian, autokorelasi diuji ketika data penelitiannya time series dan bukan ditujukan untuk data panel ataupun cross section (Gujarati, 2003:370).

\subsubsection{Hasil Uji Hipotesis}

\subsubsection{Uji T}

Tabel 8. Hasil Uji T

\begin{tabular}{llcl}
\hline Variabel & coefficient & Prob & Simpulan \\
\hline C & 10.84282 & 0.0539 & \\
CAR & 0.092782 & 0.0225 & Signifikan \\
& & & \\
LDR & -0.126873 & 0.0026 & Signifikan \\
BOPO & 0.072815 & 0.0083 & Signifikan \\
& & & Tdk \\
KAP & 0.000600 & 0.9085 & Signifikan \\
\hline
\end{tabular}

Sumber: Data diolah, 2021

Melalui tabel diatas dapat disimpulkan sebagai berikut:

Pada variabel CAR (X1) diperoleh probabilitas sebesar 0,0225 yang berarti kurang dari nilai signifikansi 0,05 dan memiliki nilai koefisien positif sebesar 0.092782. Artinya, ketika CAR mengalami peningkatan sebesar 1\%, maka menyebabkan peningkatan NPL BPR konvensional Kota Batu sebesar 0,092782. CAR mempunyai efek signifikan dan memiliki korelasi yang positif terhadap NPL. Pada variabel LDR (X2) diperoleh probabilitas sebesar 0,0026 yang berarti kurang dari nilai signifikansi 0,05 dan memiliki nilai koefisien negatif sebesar 0,126873 . Itu berarti jika LDR mengalami peningkatan sebesar $1 \%$, maka menyebabkan penurunan NPL BPR konvensional Kota Batu sebesar -0,126873. LDR mempunyai efek signifikan dan memiliki korelasi yang negatif terhadap NPL. Pada variabel BOPO (X3) diperoleh probabilitas sebesar 0,0083 yang berarti kurang dari nilai signifikansi 0,05 dan memiliki nilai koefisien positif sebesar 0,072815. Itu berarti ketika BOPO mengalami peningkatan sebesar 1\%, maka menyebabkan peningkatan NPL BPR konvensional Kota Batu sebesar 0,072815. BOPO mempunyai efek signifikan dan memiliki korelasi yang positif terhadap NPL. Pada variabel KAP (X4) diperoleh probabilitas sebesar 0,9085 yang berarti diatas nilai signifikansi 0,05 dan memiliki nilai koefisien positif sebesar 0,000600. Artinya, ketika KAP mengalami peningkatan sebesar 1\%, maka menyebabkan peningkatan NPL BPR konvensional Kota Batu sebesar 0,000600. KAP tidak berpengaruh signifikan tetapi memiliki hubungan yang positif terhadap NPL. 


\subsubsection{Uji F}

Tabel 9. Hasil Uji F

\begin{tabular}{ll}
\hline F-statistic & Prob(F-statistic) \\
\hline 39.22005 & 0.000000 \\
\hline
\end{tabular}

Sumber: Data diolah, 2021

Melalui hasil uji $\mathrm{F}$ bisa diketahui bahwa nilai F-statistic sebesar 39.22005 dengan probabilitas dari F-Statistic yaitu sebesar 0,000000 $(0,000000<0,05)$. Itu berarti memperlihatkan jika semua variabel independen yaitu CAR, LDR, BOPO, dan KAP secara bersama-sama mempunyai efek signifikan terhadap NPL.

\subsubsection{Koefisien Determinasi (R2)}

Tabel 10. Hasil Koefisien Determinasi

\begin{tabular}{lccc}
\hline & Cross-section fixed (dummy variables) & \\
\hline R-squared & 0.775176 & Mean dependent var & 10.67700 \\
Adjusted R-squared & 0.755411 & S.D. dependent var & 7.460169 \\
S.E. of Regression & 3.689498 & Akaike info criterion & 5.534547 \\
Sum squared resid & 1238.728 & Schwarz criterion & 5.769012 \\
Log likelihood & -267.7273 & Hannan-quinn criter. & 5.629439 \\
F-statistic & 39.22005 & Durbin-Watson stat & 1.071366 \\
Prob(F-statistic) & 0.000000 & & \\
\hline
\end{tabular}

Sumber: Data diolah, 2021

Melalui tabel diatas bisa dilihat jika nilai koefisien determinasi (R-square) yaitu sebesar 0.775176. Angka tersebut menunjukkan jika variabel CAR, LDR, BOPO, dan KAP pada model regresi bisa menjelaskan variabel Non Performing Loan (NPL) sebesar 77,51\%, sementara itu sisanya sebesar $22,49 \%$ dijelaskan oleh variabel lainnya diluar model penelitian.

\subsection{Pembahasan}

\subsubsection{Pengaruh CAR terhadap NPL}

Setelah melalui analisis data oleh peneliti, bisa dilihat jika CAR mempunyai efek positif dan signifikan terhadap NPL BPR konvensional di Kota Batu tahun 2015-2019. Artinya, jika CAR dalam kondisi meningkat, maka NPL pun mengalami peningkatan, sehingga kian tinggi CAR menjadikan kian tinggi rasio NPL, serta sebaliknya jika terjadi penurunan rasio CAR maka dapat menyebabkan penurunan rasio NPL.

Dalam pelaksanaan kegiatan operasional bank tentunya membutuhkan kecukupan modal untuk dapat menjalankan kegiatan usaha seperti menyalurkan kredit dan mengantisipasi risiko kerugian dari pelaksanaan kegiatan usaha tersebut. Disini CAR menjadi rasio yang bertujuan melakukan pengukuran tercukupnya modal untuk menunjang aktiva yang memiliki risiko. Munculnya risiko tentunya bisa mempengaruhi besaran modal suatu bank (Dendawijaya, 2005). Nilai CAR pada penelitian ini tergolong cukup baik karena nilainya tinggi dan sesuai dengan ketentuan minimal dari Bank Indonesia yaitu senilai 8\%. Tingginya nilai CAR tersebut mengindikasikan bahwa modal bank atau sumber daya finansialnya 
termasuk ideal. Naiknya nilai CAR kemungkinan dapat terjadi karena didasari oleh modal bank sendiri yang naik atau meningkatnya dana dari masyarakat, naiknya pinjaman, dll. Semakin tinggi rasio CAR membuat bank meningkatkan pengembangan usahanya seperti ekspansi untuk penyaluran kredit, sebab modal yang besar membuat bank percaya diri dalam menyalurkan kreditnya, namun risiko peningkatan NPL menjadi lebih besar.

Hasil penelitian ini sejalan dengan Anthony \& Nakita (2018) yang menyebutkan jika CAR mempunyai efek positif signifikan terhadap NPL. Hasil itu menunjukkan jika nilai CAR naik membuat rasio NPL akan ikut naik, demikian pun sebaliknya.

\subsubsection{Pengaruh LDR terhadap NPL}

Berdasarkan hasil analisis data oleh peneliti, bisa dilihat jika LDR mempunyai pengaruh negatif dan signifikan terhadap NPL BPR konvensional di Kota Batu tahun 2015-2019. Artinya, jika LDR dalam kondisi meningkat, maka NPL pun mengalami penurunan, sehingga kian tinggi LDR membuat kian turun nilai rasio NPL, dan sebaliknya apabila rasio LDR menurun menjadikan nilai NPL akan naik.

Rasio LDR pun menjadi sebuah isyarat atau petunjuk apakah pinjaman akan dibatasi ataukah masih bisa melakukan ekspansi. Jika LDR suatu bank tinggi menyebabkan bank dapat meningkatkan penyaluran kreditnya sehingga memiliki risiko sulit tertagihnya tunggakan kredit dan hal tersebut dapat mengakibatkan bank mengalami kerugian (Latumaerissa, 2014). Pada penelitian ini apabila terdapat peningkatan DPK yang dihimpun dari nasabah/masyarakat seperti simpanan deposito berjangka \& tabungan, kemudian DPK tersebut akan terkumpul banyak sehingga membuat bank menggunakan dana tersebut untuk penyaluran kredit. Namun, bank lebih selektif serta berhati-hati dalam menyalurkan kredit karena bank terlebih dahulu menilai kualitas calon debitur terutama dari prinsip 5C (Condition, Capacity, Capital, Collateral, dan Character), dimana hal tersebut membuat risiko kredit macet akan menurun sehingga rasio NPL akan menurun juga. Selain itu, tingginya pemberian pinjaman membuat keuntungan bank juga ikut naik dengan adanya asumsi bahwa bank seperti BPR ini memiliki kemampuan untuk mengalirkan kredit dengan efektif, sehingga total kredit macet tergolong kecil dan rasio NPL menurun.

Hasil penelitian ini sejalan dengan Shinta Anggun Kinanti (2017) yang menyebutkan jika LDR mempunyai efek negatif signifikan terhadap NPL.

\subsubsection{Pengaruh BOPO terhadap NPL}

Berdasarkan hasil analisis data oleh peneliti, bisa dilihat jika BOPO mempunyai efek positif serta signifikan terhadap NPL BPR konvensional Kota Batu tahun 2015-2019. Artinya, jika BOPO dalam kondisi meningkat, maka NPL pun akan mengalami peningkatan, lalu menyebabkan kian tingginya nilai BOPO menjadikan kian tinggi pula rasio NPL. Sebaliknya, jika terjadi penurunan rasio BOPO maka dapat menyebabkan penurunan rasio NPL.

Rasio BOPO berfungsi dalam melihat keahlian manajemen suatu bank ketika mengatur pendapatan dan biaya (Kuncoro dan Suhardjono, 2009). Seiring perannya sebagai lembaga intermediasi maka biaya bunga serta hasil bunga mendominasi biaya dan pendapatan suatu bank (Dendawijaya, 2009:111). Adanya pemasukan bank yang besar bisa menutup potensi kerugian yang dialami bank, lalu peningkatan modal bakal mempermudah bank dalam 
pembiayaan aktiva yang didalamnya ada risiko. Kian naiknya rasio BOPO memberi sinyal bahwa bank dalam mengelola pembiayaannya masih jauh dari kata efisien, pengeluaran bank tinggi dalam hal biaya operasionalnya sehingga memberikan dampak bagi penurunan tingkat pengembalian yang dihasilkan. Agar bisa meningkatkan tingkat pengembalian, maka diperlukan kebijakan oleh bank agar tingkat suku bunga bisa naik, sehingga hal itu berdampak pada peningkatan gagal bayar pada debitur yang ujungnya akan mengakibatkan peningkatan risiko kredit bermasalah atau peningkatan rasio NPL.

Hasil penelitian ini sama dengan Shinta Anggun Kinanti (2017) yang menyebutkan jika BOPO mempunyai efek positif signifikan terhadap NPL

\subsubsection{Pengaruh KAP terhadap NPL}

Melalui penelitian ini diperlihatkan jika KAP tidak terdapat pengaruh signifikan, namun memiliki korelasi positif terhadap NPL BPR konvensional Kota Batu tahun 2015-2019. Artinya, jika KAP naik, maka NPL tak ikut naik sebab tidak mempunyai pengaruh signifikan.

KAP bermasalah dapat meliputi kualitas kredit diragukan, macet, dan kurang lancar dengan menggambarkan besarnya aset bermasalah dan tidak memberikan pemasukan untuk bank (Taswan, 2010). Kriteria debitur yang tak sesuai membuat komposisi pinjaman juga tak tepat sasaran yang mana ujung-ujungnya meningkatkan KAP bermasalah. Total angsuran kredit debitur yang masih mengalami penundaan pembayaran atau pembayarannya tidak dapat dilunasi menjadi petunjuk dalam melihat besarnya KAP bermasalah. Hal itu tentunya menurunkan kualitas kredit sehingga berdampak pada meningkatnya NPL. Ketidaksamaan hasil penelitian dengan hipotesis mungkin bisa diakibatkan oleh kualitas kredit yang masih dalam batas wajar dan tidak banyak terjadinya penundaan pembayaran angsuran ataupun gagalnya pelunasan pembayaran, jika terdapat penundaan pembayaran angsuran pihak bank memberikan tenggat waktu untuk melakukan pembayaran lagi atau debitur memperoleh toleransi dengan melakukan mencicil angsuran lebih rendah dari yang disepakati kedua belah pihak sebelumnya, sehingga hal tersebut membuat KAP tidak begitu berpengaruh terhadap peningkatan rasio NPL.

Hasil dari penelitian ini memiliki perbedaan hasil dengan M.Umar \& Gang Sun (2018) serta Selamet Riyadi, dkk (2015) yang menyatakan jika KAP mempunyai pengaruh positif signifikan terhadap NPL.

\subsubsection{Pengaruh CAR, LDR, BOPO, dan KAP Terhadap NPL BPR Konvensional Kota Batu 2015-2019 (Sebelum COVID-19)}

Setelah melakukan analisis regresi data panel memakai FEM bisa dilihat jika variabel CAR, LDR, BOPO, dan KAP secara simultan menunjukkan nilai probabilitas (F-statistic) sebesar 0,000000 dan kurang dari nilai signifikansi 0,05 . Tandanya variabel independen seluruhnya mempunyai efek secara simultan terhadap NPL BPR konvensional di Kota Batu pada periode triwulan 2015-2019 (sebelum COVID-19). H5 yang berbunyi "CAR, LDR, BOPO, dan KAP berpengaruh secara simultan terhadap NPL BPR konvensional di Kota Batu sebelum dan setelah COVID-19" dapat diterima. Hasil estimasi menggunakan model FEM memperlihatkan jika koefisien determinasi (R-square) yaitu sebesar 0.775176. Nilai itu memperlihatkan jika variabel CAR, LDR, BOPO, dan KAP pada model regresi bisa menjelaskan variabel NPL sebesar $77,51 \%$, lalu sisanya sebesar $22,49 \%$ dijelaskan oleh variabel lainnya diluar model penelitian. 


\subsubsection{Analisis Deskriptif}

Tabel 11. Hasil Statistik Deskriptif NPL

\begin{tabular}{cccccc}
\hline Variabel & N & Minimum & Maksimum & Mean & Std. Dev. \\
\hline NPL Sebelum Pandemi & 5 & 0.870 & 26.750 & 12.999 & 9.106 \\
NPL Saat Pandemi & 5 & 1.520 & 33.770 & 18.214 & 10.143 \\
\hline
\end{tabular}

Sumber: Data diolah, 2021

Peningkatan rasio NPL pada tahun 2020 ini bukannya tanpa alasan, sebab para debitur kesulitan membayar/melunasi kewajibannya imbas dari pendapatan mereka yang menurun karena saat terjadi COVID-19 dampaknya dirasakan oleh berbagai bidang. Banyak orang yang di-PHK, dirumahkan, dipotong gajinya, ataupun penjualan sepi imbas dari COVID-19 sehingga berpengaruh ketika memiliki angsuran di bank seperti BPR konvensional dengan tidak mampu mengangsur di bank sebagaimana mestinya. Kebijakan restrukturisasi kredit yang dilakukan bank juga dilakukan untuk mengatasi kredit yang berpotensi menjadi kredit bermasalah.

Tabel 12. Hasil Statistik Deskriptif CAR

\begin{tabular}{cccccc}
\hline Variable & N & Minimum & Maksimum & Mean & Std. Dev. \\
\hline CAR Sebelum Pandemi & 5 & 12.100 & 99.390 & 56.524 & 24.293 \\
CAR Saat Pandemi & 5 & 13.690 & 174.350 & 91.576 & 52.433 \\
\hline
\end{tabular}

Sumber: Data diolah, 2021

Umumnya rasio CAR pada rentang tahun 2015-2020 secara menyeluruh bisa disimpulkan baik sebab angkanya di atas $8 \%$ sesuai acuan yang diputuskan Bank Indonesia. Saat pandemi COVID-19 modal bank dan dana dari masyarakat cenderung meningkat, masyarakat banyak yang menyimpan uangnya di bank seperti melalui tabungan ataupun simpanan deposito agar dapat memperoleh pendapatan tambahan dari bunga simpanan tersebut yang tentunya berdampak positif ketika di masa pandemi. Jumlah pinjaman yang dilakukan oleh debitur juga cukup tinggi saat masa pandemi karena masyarakat membutuhkan uang untuk bertahan hidup, sedangkan pendapatan ketika masa pandemi menurun akibat imbas dari COVID-19. Tambahan modal bank yang banyak tentunya membuat bank akan lebih gencar menyalurkan kredit yang mana bisa berimbas pada kenaikan risiko kredit bermasalah.

Tabel 13. Hasil Statistik Deskriptif LDR

\begin{tabular}{cccccc}
\hline Variabel & N & Minimum & Maksimum & Mean & Std. Dev. \\
\hline LDR Sebelum Pandemi & 5 & 54.200 & 101.600 & 78.524 & 13.854 \\
LDR Saat Pandemi & 5 & 26.530 & 293.630 & 72.529 & 54.175 \\
\hline
\end{tabular}

Sumber: Data diolah, 2021

Penyaluran kredit dan penghimpunan dana yang menurun pada awal-pertengahan 2020 dapat disebabkan oleh bank yang tidak mau tergesa-gesa dan gencar dalam menyalurkan dananya kepada masyarakat dikarenakan saat itu memasuki masa-masa awal pandemi yang membuat bank khawatir jika gencar menyalurkan dana kepada masyarakat membuat risiko terjadinya kredit bermasalah menjadi tinggi. Penyaluran kredit yang tinggi ketika memasuki periode terakhir 2020 dikarenakan masyarakat banyak yang membutuhkan dana untuk memenuhi kebutuhan hidupnya, sementara itu banyak dari mereka yang pendapatannya menurun imbas dari pandemi, oleh karena itu bank seperti BPR melihat fenomena di lapangan lalu melakukan langkah untuk menyalurkan kredit kepada masyarakat yang butuh dana. 
Meskipun secara rata-rata rasio LDR menurun dari sebelum pandemi tetapi ada pula bank yang rasio LDR nya tergolong sangat tinggi, hal itu juga dikhawatirkan berimbas pada naiknya nilai NPL.

Tabel 14. Statistik Deskriptif BOPO

\begin{tabular}{cccccc}
\hline Variabel & N & Minimum & Maksimum & Mean & Std. Dev. \\
\hline BOPO Sebelum Pandemi & 5 & 62.420 & 159.490 & 88.195 & 24.717 \\
BOPO Saat Pandemi & 5 & 0.000 & 170.160 & 90.381 & 35.026 \\
\hline
\end{tabular}

\section{Sumber: Data diolah, 2021}

Pada masa pandemi bank masih belum efisien dalam mengelola pembiayaannya (biaya operasional untuk penyaluran kredit belum efisien), sehingga memberikan dampak bagi penurunan tingkat pengembalian yang dihasilkan. Pendapatan yang diperoleh bank dari penyaluran kredit pada masa pandemi masih belum bisa menutupi biaya operasional yang digunakan untuk kegiatan penyaluran kredit, hal itu berimbas pada meningkatnya rasio BOPO pada masa pandemi. Dengan belum efisiennya bank dalam menyeimbangkan antara biaya dan pendapatan membuat potensi kerugian di masa pandemi jauh lebih besar dan risiko naiknya NPL juga lebih tinggi.

Tabel 15. Hasil Statistik Deskriptif KAP

\begin{tabular}{cccccc}
\hline Variabel & N & Minimum & Maksimum & Mean & Std.Dev \\
\hline KAP Sebelum Pandemi & 5 & 2.690 & 24.660 & 11.833 & 6.308 \\
KAP Saat Pandemi & 5 & 2.670 & 112.050 & 17.661 & 23.295 \\
\hline
\end{tabular}

Sumber: Data diolah, 2021

Rasio KAP bermasalah pada periode saat terjadi COVID-19 (tahun 2020) tergolong baik karena komposisi pinjaman telah memenuhi kriteria yang berlaku. Jumlah angsuran kredit yang masih tertunda dan belum dilunasi pembayarannya cukup sedikit sehingga KAP bermasalah tidak terlalu besar. Kualitas kredit yang dimiliki bank juga lebih baik pada periode 2020 dibandingkan periode sebelumnya. Dapat dikatakan bank saat itu mengerti mengenai mampu tidaknya nasabah dalam melakukan pembayaran kewajiban kepada bank, kemudian kondisi itu bisa menurunkan risiko kredit bermasalah karena menurunnya jumlah aset bermasalah. Rasio KAP yang menyentuh angka 112,05\% dan mean yang meningkat menjadi $17,66 \%$ diakibatkan oleh peningkatan rasio KAP di salah satu bank secara drastis, di satu sisi pada bank lainnya banyak yang tergolong baik rasio KAP di bank tersebut.

\section{Simpulan}

Melalui pembahasan yang sudah diulas bisa disimpulkan sebagai berikut:

CAR mempunyai pengaruh positif dan signifikan terhadap NPL. Artinya, jika CAR meningkat maka rasio NPL juga meningkat, begitu juga sebaliknya. Besarnya CAR bisa meningkatkan keahlian bank untuk menggenjot ekspansi usahanya, misalnya untuk kegiatan penyaluran pinjaman sebab jika cadangan modal bertambah besar membuat bank memiliki dana yang akan berguna dalam menutup kerugian yang timbul akibat penyaluran kredit. Hal itu membuat bank semakin percaya diri untuk menyalurkan kreditnya, namun risiko peningkatan NPL menjadi lebih besar. Pada tahun 2020 saat terjadi pandemi, nilai CAR juga 
meningkat dibandingkan sebelumnya sehingga membuat bank dapat mengembangkan usahanya melalui penyaluran kredit di masa pandemi dengan peningkatan rasio NPL sebagai dampaknya.

LDR mempunyai pengaruh negatif dan signifikan terhadap NPL. Jikalau LDR naik menjadikan rasio NPL malah menurun, jika LDR menurun maka rasio NPL meningkat. LDR tidak bisa dilepaskan dari DPK, peningkatan DPK membuat bank menggunakan dana tersebut untuk penyaluran kredit. Penyaluran kredit yang tinggi maka laba bank juga ikut naik dengan asumsi bahwa BPR ini bisa memberikan pinjaman secara efisien \& efektif, sehingga total kredit macet tergolong kecil dan rasio NPL menurun. Pada masa pandemi nilai LDR meningkat pada periode triwulan keempat karena bank juga gencar menyalurkan kredit, adanya laba dan seleksi debitur-lah yang membuat risiko kredit macet akan menurun.

BOPO mempunyai pengaruh positif dan signifikan terhadap NPL. Berarti apabila nilai BOPO naik berimbas pada rasio NPL yang meningkat, begitu juga sebaliknya. Tingginya BOPO memberi sinyal bahwa bank tak efisien ketika mengatur pembiayaannya, biaya operasional bank tinggi serta pendapatan rendah, sehingga memberikan dampak bagi penurunan tingkat pengembalian yang dihasilkan. Agar bisa meningkatkan tingkat pengembalian, bank bisa melakukan kebijakan untuk meningkatkan tingkat suku bunga sehingga hal itu berdampak pada peningkatan gagal bayar pada debitur yang ujungnya akan mengakibatkan peningkatan risiko kredit bermasalah. Pada masa pandemi rasio BOPO juga meningkat dibandingkan tahun 2019, hal itu menandakan bahwa bank masih belum efisien, lalu pendapatan dari penyaluran kredit masih belum dapat menutupi biaya operasionalnya

KAP tidak berpengaruh signifikan dan positif terhadap NPL BPR konvensional di Kota Batu. Kualitas kredit yang masih dalam batas wajar dan tidak banyak terjadinya penundaan pembayaran angsuran ataupun gagalnya pelunasan pembayaran, jika terdapat penundaan pembayaran angsuran pihak bank memberikan tenggat waktu untuk melakukan pembayaran lagi atau debitur memperoleh toleransi dengan melakukan mencicil angsuran lebih rendah dari yang disepakati kedua belah pihak sebelumnya, sehingga hal tersebut membuat KAP tidak begitu berpengaruh terhadap peningkatan rasio NPL. Pada masa pandemi rasio KAP bermasalah cukup sedikit dan cenderung menurun dari periode sebelumnya. Dapat dikatakan bank saat itu mengerti mampu tidaknya debitur ketika melakukan pembayaran kewajiban, kemudian atas dasar itulah risiko kredit bermasalah bisa dikontrol sebab total aset bermasalah berkurang.

Variabel independen yang menyeluruh yaitu CAR, LDR, BOPO, dan KAP mempunyai pengaruh terhadap NPL BPR konvensional di Kota Batu secara simultan.

\section{Daftar Rujukan}

Barua, Bipasha dan Suborna Barua. (2021). COVID-19 implications for banks: evidence from an emerging economy. SN Business \& Economics, 1(1), 1-28.

Brigham \& Houston. (2014). Essentials of Financial Management. Dasar-dasar Manajemen Keuangan. Terjemahan Ali Akbar Yulianto. Buku 2. Edisi 11. Jakarta: Salemba Empat.

Dendawijaya, Lukman. (2005). Manajemen Perbankan. Jakarta: Ghalia Indonesia.

El-Maude, J.G., Abdul-Rehman, A. \& Ibrahim, M. (2017). Determinants of Non-Performing Loans in Nigeria's Deposit Money Banks. Archive of Business Research. Vol 5 (1) : 74-88.

Ghozali, Imam. (2007). Aplikasi Analisis Multivariate Dengan Program SPSS. Semarang: Badan Penerbit Universitas Diponegoro. 
Gujarati, D. N. (2012). Dasar-dasar Ekonometrika. Terjemahan Mangunsong, R. C. Buku 2 Edisi 5. Jakarta: Salemba Empat.

Kasmir. (2014). Bank dan Lembaga Keuangan Lainnya. Jakarta: PT Rajagrafindo Persada.

Khan, M.A., Siddique, A. \& Sarwar, Z. (2020). Determinants of Non-Performing Loans in the Banking Sector in Developing State. Asian Journal of Accounting Research. Vol 5 (1) : 135-145.

Kinanti, Shinta Anggun. (2017). Pengaruh BOPO, LDR, dan ROA Terhadap NPL Pada Bank Persero yang Terdaftar di Bursa Efek Indonesia (BEI) Periode 2006-2012. Jurnal Ilmu Manajemen FE UNESA. Vol 5 (1) : $1-9$.

Latumaerissa, Julius R. (2014). Manajemen Bank Umum. Jakarta: Mitra Wacana Media.

Martina, Emy dan Dewi Prastiwi. (2014). Pengaruh Inflasi, Gross Domestic Product, Suku Bunga Kredit, Loan to Asset Ratio, dan Kualitas Aktiva Produktif Terhadap Non Performing Loan. Jurnal Ilmu Manajemen FE UNESA. Vol 2 (2) : 513-524.

Mentari, S. H. (2017). Pengaruh CAR, LDR dan BOPO terhadap Non Performing Loan Bank Umum di Indonesia (Doctoral dissertation, STIE PERBANAS SURABAYA).

Mukhlis, Imam. (2015). Ekonomi Keuangan dan Perbankan: Teori dan Aplikasi, Jakarta : Salemba.

Mukhlis, Imam, Isnawati Hidayah, Nora Ria Retnasih. (2020). Interest Rate Volatility of the Federal Funds Rate : Response of the Bank Indonesia and its Impact on the Indonesian Economic Stability.Journal of Central Banking Theory and Practice. Vol 9 : 111-133.

Prasanth, S dkk. (2020). Factors Affecting Non Performing Loan in India. International Journal of Scientific \& Technology Research. Vol 9 (1) : 1654-1657.

Rachman, Rathria Arrina dkk. (2018). Bank-specific Factors Affecting Non-performing Loans in Developing Countries : Case Study of Indonesia. Journal of Asian Finance, Economics, and Business. Vol 5 (2) : 35-42.

Riyadi, Selamet dkk. (2015). Strategi Pengelolaan Non Performing Loan Bank Umum yang Go Public. Jurnal Dinamika Manajemen. Vol 6 (1) : 84-96.

Rosita, Maya dan Musdholifah. (2016). Pengaruh Makroekonomi, Capital Adequacy Ratio, Loan to Deposit Ratio, dan Pertumbuhan Kredit Terhadap Non Performing Loan Pada Bank Asing di Indonesia Periode 2013-2014. Jurnal Bisnis dan Manajemen Unesa. Vol 8 (2) : 124-143.

Ryzkita, Lia dan M Jusmansyah. (2017). Analisis Pengaruh Rasio CAR, LDR, Dan BOPO Terhadap Non Performing Loan Studi Empirik Pada Bank Swasta Nasional Periode 2007 - 2010. Jurnal Ekonomika dan Manajemen. Vol 6 (2).

Sugiyono. (2017). Metode Penelitian Kuantitatif, Kualitatif, dan R\&D. Bandung : Alfabeta, CV.

Taswan. (2010). Manajemen Perbankan Konsep Teknik \& Aplikasi Edisi II. Yogyakarta: UPP STIM YKPN Yogyakarta.

Tiwu, Maria Indriyani Hewe. (2020). Pengaruh Pandemic COVID 19 Terhadap NPL Bank Perkreditan Rakyat di Indonesia. Jurnal Akuntansi: Transportasi dan Akuntabilitas. Vol 8 (2) : 79-87.

Umar, Muhammad dan Gang Sun. (2018). Determinants of Non-Performing Loansin Chinese Banks. Journal of Asia Business Studies. Vol 12 (3)

Widarjono, Agus. (2013). Ekonometrika : Pengantar dan Aplikasinya. Yogyakarta: UPP STIM YKPN.

Wood, Anthony dan Nakita Skinner. (2018). Determinants of Non-Performing Loans : Evidence From Commercial Banks in Barbados. The Business and Management Review. Vol 9 (3) : 44-64. 